\title{
UPAYA DINAS KESEHATAN DALAM MENCEGAH PENYEBARAN PENYAKIT HIV AIDS DI KABUPATEN BUNGO
}

Joko Susanto

STIA Setih Setio Muara Bungo, Jambi

jokosusantoo251@gmail.com

\section{ARTIKEL INFO}

Keywords: Health Service Efforts, Preventing the Spread of HIV AIDS, Bungo District.

\begin{abstract}
Bungo Regency is one of the autonomous regions in Jambi Province. Bungo Regency is an area that shows rapid development in all fields. These developments have a negative impact which one of these impacts is the rampant drug abuse and covert prostitution. Even though these two factors are the main mediators of the spread of HIV / AIDS. The purpose of this study was to find out about the health service's efforts in preventing the spread of HIV AIDS in Bungo District. The method used in this research is descriptive method with a qualitative approach. In this study the population was the Bungo District Health Office and the Bungo District community as a validity test, the number of samples was 12 informants, consisting of 7 informants from the Health Office and 5 informants from the community.

The data collection techniques are through observation, interviews and document review. Processing data is taken from primary data sourced from interviews, secondary data through theoretical analysis sourced from books, reports, and photographs. The results showed that the Health Service's efforts to prevent the spread of HIV / AIDS in Bungo District through various comprehensive measures, including preventive, promotive, curative, and rehabilitative with broad participation and cooperation involving various sectors and non-governmental organizations and communities has been good enough and has progressed but still needs to be improved so that Bungo Regency can be cleared of HIV / AIDS.
\end{abstract}

\section{PENDAHULUAN}

Acquired Imune Deficiency Syndrome (AIDS) didefinisikan sebagai suatu sindrom atau kumpulan gejala penyakit dengan karakteristik defisiensi kekebalan tubuh yang berat dan merupakan manifestasi stadium akhir HIV (Notoatmodjo, 2007). HIV merupakan singkatan dari Human Immunodeficiency Virus (virus defisiensi imun manusia atau virus penurun kekebalan manusia). Virus HIV yang menjadi penyebab AIDS, masuk ke dalam tubuh manusia dan berdiam di dalam sel, untuk kemudian menggunakan metabolisme sel untuk memperbanyak diri dan berkembang (Budi Setyo W, 2009). HIV menjadi penyebab utama turunnya sistem imun sekunder, yang lambat laun akan mengarah pada stadium AIDS. Padahal integritas sistem imun sangat diperluhkan untuk mempertahankan diri terhadap mikroorganisme dan produk toksik yang dihasilkan (Kresno, 2010).

AIDS atau Acquired Immune Deficiency Sindrome (Sindrom Cacat Dapatan pada Ilmunitas) merupakan kumpulan gejala penyakit akibat menurunnya sistem kekebalan tubuh oleh virus yang disebut HIV (Jhonatan Weber dan Annabel Ferriman, 1993). Ini adalah inveksi virus yang bisa menyebabkan kerusakan yang parah dan tidak bisa diobati pada sistem imunitas, sehingga korbannya terbuka terhadap infeksi dan kanker tertentu. Kerusakan progresif pada sistem kekebalan tubuh menyebabkan ODHA (orang dengan HIV/AIDS) amat rentan dan mudah terjangkit bermacam-macam penyakit. Serangan penyakit yang biasanya tidak berbahaya pun lama-kelamaan akan menyebabkan pasien sakit parah bahkan meninggal.

Fenomena AIDS telah menjadi stigma sosial yang dampaknya tidak hanya dari sisi medis saja, akan tetapi hingga kehidupan bermasyarakat. Stigma sosial ini bahkan memiliki akibat yang yang luas, di luar akibat langsung yang disebabkan oleh penyakit tersebut. Bahkan, stigma ini juga ikut menimpa petugas kesehatan dan sukarelawan yang terlibat merawat orang yang hidup mengidap AIDS.

Selain dampak dari sisi medis, penyebaran penyakit AIDS ini diperlukan tindakan non medis. Sementara tindakan medis masih dalam tahap perkembangan dan penelitian, masalah non medis akan 
menjadi penghalang dalam upaya pencegahan dan penularannya di masyarakat. Masalah non medis ini terletak pada manusia, meliputi pola fikir yang tidak berubah dari manusia itu, sementara lingkungannya sudah berubah. Mayoritas manusia masih belum mampu menerima keberadaan virus HIV di dunia ini. Bahkan petugas kesehatan yang masih saja ada yang belum mau dan belum mampu memahami virus HIV dan penyakit AIDS. Suatu kondisi yang mengironiskan tentunya.

Selain itu masih terdapatnya sikap diskriminasi dan rasa apatis masyarakat terhadap pasien pengidap HIV dan penderita AIDS yang sering disebut dengan Orang Dengan HIV/AIDS (ODHA), sehingga dukungan untuk pasien sangat kurang di kalangan keluarga. Pasien layaknya orang yang terkutuk, tak bermoral, dan harus dijauhi. Padahal, dengan menangani satu pengidap HIV, berarti kita sudah menangani satu sumber penularan, dan dapat mencegah penularannya kepada orang lain.

Permasalahan tersebut perlu diatasi dengan pendekatan pelayanan kesehatan primer komprehensif yang langsung menyentuh akar permasalahan mencakup masalah sosial ekonomi dan lingkungan kultural. Strategi tersebut dilakukan melalui berbagai langkah yang bersifat menyeluruh, meliputi tindakan sebagai berikut (Fadilah Islami, 2006:25) :

1. Preventif

Yaitu tindakan pencegahan sebelum terjadi penyebaran penyakit HIV/AIDS.

2. Promotif.

Yaitu tindakan berupa pemberian informasi mengenai bahaya HIV/AIDS pada masyarakat.

3. Kuratif.

Yaitu tindakan efektif berupa pengobatan medis terhadap pengidap HIV/AIDS.

4. Rehabilitatif.

Yaitu tindakan penanganan secara psikis kepada para pengidap HIV/AIDS untuk tetap melakukan hal positif dalam hidupnya dan diikutsertakan dalam menanggulangi HIV/AIDS.

Dengan partisipasi dan kerja sama yang luas yang melibatkan berbagai sektor, organisasi non pemerintah dan masyarakat serta tentu saja yang paling utama adalah pemerintah melalui Dinas Kesehatan sebagai suatu instansi yang bertanggung jawab menangani segala hal yang berkitan dengan kesehatan.

Provinsi Jambi sangat rawan terhadap kemungkinan menyebarluasnya kasus HIV/AIDS, karena letaknya dikelilingi dan berbatasan langsung dengan Provinsi tetangga yang mempunyai prevalensi HIV/AIDS relatif tinggi. Kabupaten Bungo adalah salah satu daerah otonom yang berada di provinsi Jambi. Kabupaten Bungo merupakan daerah yang menunujukkan perkembangan pesat dalam segala bidang. Perkembangan tersebut memberikan dampak negatif yang mana salah satu dampak tersebut adalah maraknya penyalahgunaan narkoba dan prostitusi terselubung. Padahal dua faktor tersebut adalah mediator penyebaran HIV/AIDS yang paling utama.

Maraknya pemakai narkoba terutama dikalangan remaja perlu diwaspadai terlebih lagi Kabupaten Bungo adalah daerah yang sedang berkembang. Sebagaimana dipersepsikan di atas bahwa penggunaan narkoba yang menggunakan jarum suntik secara komunal akan memudahkan untuk penularan infeksi HIV / AIDS. Selain itu, merebaknya gaya hidup bebas dikalangan generasi muda telah menjadi tren di daerah yang sedang beranjak maju seperti Kabupaten Bungo menjadi salah satu faktor penyebaran HIV / AIDS. Hal tersebut bukanlah isapan jempol dan kita dapat melihatnya langsung telah terjadi pergeseran budaya ke arah hedonisme di Kota Bungo.

Menurut pengamatan peneliti, ada beberapa faktor yang dapat menjadi penyebab penyebaran HIV/AIDS di Kabupaten Bungo yaitu sebagai berikut:

1. Maraknya pola pergaulan yang cenderung bebas pada kalangan muda di Kabupaten Bungo;

2. Mudahnya akses terhadap situs-situs dan pengambilan akun berbau pornografi sehingga mengakibatkan meningkatnya jumlah aktivitas pornoaksi ilegal seperti adanya tempat prostitusi;

3. Minimnya pemahaman masyarakat terutama para generasi muda tentang HIV/AIDS; dan

4. Maraknya pemakaian narkoba suntik secara komunal yang rentan terhadap penyebaran HIV/AIDS.

Beberapa faktor di atas tidak dapat dipandang sebelah mata, karena efeknya akan merebaknya penyakit HIV/AIDS di Kabupaten Bungo. Penanggulangan HIV/AIDS di masyarakat memerlukan keterlibatan seluruh elemen masyarakat, mulai dari generasi muda, tokoh agama, tokoh adat, tokoh 
masyarakat, organisasi, lembaga swadaya masyarakat dan yang paling utama adalah keterlibatan dari pemimpin masyarakat dan para pengambil keputusan dan kebijakan.

Penelitian tentang pencegahan penyakit HIV/AIDS telah dilakukan oleh beberapa peneliti sebelumnya, salah satu penelitian sebelumnya yang diteliti oleh Alexander O. Maengkom yang berjudul "Analisis Tindakan Pencegahan Penularan HIV/AIDS Di Klinik Hohidiai Kusuri Kecamatan Tobelo Barat Kabupeten Halmahera Utara". Hasil penelitian di atas menunjukkan Analisis pencegahan penularan HIV lewat kontak seksual di Kabupaten Halmahera Utara yaitu pihak pemerintah selalu bekerja sama dengan pihak-pihak terkait dalam hal ini Dinas Kesehatan dan Penggelola Program yaitu pencegahan penularan HIV/AIDS lewat sosialisasi di berbagai tempat dan semua kalangan termasuk kelompok beresiko terjadi penularan HIV/AIDS, Tindakan pencegahan penularan HIV lewat kontak nonseksual menunjukan hasil bahwa penggunaan IDU selalu steril karena digunakan sekali pakai contoh jarum sutik, sedangkan Analisis Tindakan mencegah risiko Infeksi Oputunistik, Taat Minum ART dan Status psikologis: Tidak ada stigma negatif, yaitu dalam mencegah Resiko Infeksi Oputunistik diharapkan untuk menjaga kesehatan terlebih kebersihan diri, dan untuk taat minum obat penderita HIV selalu taat minum obat tetapi ada juga yang tidak minum obat dengan alasan malu, sedangkan Stigma masyarakat mengenai HIV masih sangat tinggi karena takut tertular penyakit mematikan yang belum ada obatnya, akan tetapi untuk petugas kesehatan di klinik hohidia tobelo sudah tidak ada stigma negatif.

Penelitian di atas menunjukkan ada relevansi dengan apa yang akan di bahas paa penelitian ini yaitu terkait dengan upaya pencegahan penyakit HIV/AIDS. Dinas Kesehatan Kabupaten Bungo sebagai unit pelaksana yang berkaitan dengan bidang kesehatan di Kabupaten Bungo merupakan stakeholder utama dalam kaitannya dengan penanganan penyebaran penyakit AIDS melalui Seksi Pengendalian dan Pemberantasan Penyakit. Oleh karena itu, penelitian ini bertujuan untuk mengetahui Upaya apa saja yang dilakukan oleh Dinas Kesehatan untuk mencegah penyebaran penyakit HIV/AIDS di Kabupaten Bungo.

\section{METODE PENELITIAN}

Metode penelitian pada dasarnya merupakan cara ilmiah untuk mendapatkan data dengan tujuan dan kegunaan tertentu (Sugiyono, 2010). Adapun metode yang digunakan dalam penelitian ini adalah metode deskriptif dengan pendekatan kualitatif yakni untuk mengetahui, menjelaskan, dan mendiskripsikan upaya Dinas Kesehatan dalam mencegah penyebaran penyakit HIV AIDS di Kabupaten Bungo. Populasi merupakan wilayah generalisasi yang terdiri atas obyek/subyek yang mempunyai kuantitas dan karakteristik tertentu yang ditettapkan oleh peneliti untuk dipelajari dan ditarik kesimpulannya (Muhammad Mulyadi, 2012). Dalam penelitian ini yang menjadi populasi adalah pegawai Dinas Kesehatan Kabupaten Bungo dan masyarakat Kabupaten Bungo sebagai uji validitas. Sampel adalah sebagian anggota populasi yang diambil dengan menggunakan teknik tertentu dari sebuah populasi yang di sebut tekhnik purposive sampling (Husaini Usman dan Purnomo Setiadi. A, 2003:22). Jumlah sampel sebanyak 12 informan, terdiri dari 7 informan dari Dinas Kesehatan dan 5 informan dari masyarakat. Dalam penelitian ini, peneliti menggunakan teknik pengumpulan data yakni dengan melakukan observasi, wawancara, dokumentasi, dan triagulasi/gabungan.

\section{Sumber Data}

Data primer adalah data yang diperoleh dari lokasi penelitian yang berupa wawancara dan data ini masih murni dan belum diolah dalam proses tertentu.

Data sekunder adalah data yang diperoleh dalam bentuk sudah diolah dan dipublikasikan. Data ini berbentuk buku-buku laporan dan bahan-bahan dokumenter, baik yang dikeluarkan oleh lembaga pemerintah maupun non pemerintah khususnya data mengenai kegiatan pemerintah daerah.

Suatu hal yang sangat penting dalam suatu penelitian adalah menganlisis data, karena hal ini dapat memberikan arti dan makna dalam suatu penelitian. Dalam penelitian ini, teknik pengelolaan data yang dikumpulkan melalui studi pustaka dan studi lapangan yang didapatkan dari observasi tempat penelitian dengan melalui wawancara dengan responden. 


\section{HASIL DAN PEMBAHASAN}

Kabupaten Bungo sebagai salah satu daerah Kabupaten/kota dalam Provinsi Jambi. Kabupaten Bungo memiliki luas wilayah sekitar $4.659 \mathrm{~km}^{2}$. Kabupaten Bungo memiliki 17 kecamatan, 12 kelurahan dan 141 desa (dari total 141 kecamatan, 163 kelurahan dan 1.399 desa di seluruh Jambi). Pada tahun 2017, jumlah penduduknya sebesar 332.881 jiwa. Wilayah ini secara geografis terletak pada posisi $101^{\circ} 27^{\prime}$ sampai dengan $102^{\circ} 30^{\prime}$ Bujur Timur dan di antara $1^{\circ} 08^{\prime}$ hingga $1^{\circ} 55^{\prime}$ Lintang Selatan. Berdasarkan letak geografisnya Kabupaten Bungo berbatasan dengan Kabupaten Tebo dan Kabupaten Dharmasraya di sebelah Utara, Kabupaten Tebo di sebelah Timur, Kabupaten Merangin di sebelah Selatan, dan Kabupaten Kerinci di sebelah Barat. Wilayah Kabupaten Bungo secara umum adalah berupa daerah perbukitan dengan ketinggian berkisar antara 70 hingga $1300 \mathrm{M}$ dpl, di mana sekitar $87,70 \%$ di antaranya berada pada rentang ketinggian 70 hingga $499 \mathrm{M}$ dpl. Sebagian besar wilayah Kabupaten Bungo berada pada Sub Daerah Aliran Sungai (Sub-Das) Sungai Batang Tebo. (BPS Kabupaten Bungo 2018).

Masalah HIV/AIDS di Indonesia diyakini bagaikan fenomena gunung es (Iceberg Phenomenon) karena laporan resmi jumlah kasus tidak mencerminkan masalah yang sebenarnya. Prediksi besar masalah HIV/AIDS tersebut didasarkan atas jumlah penyalahgunaan narkotika suntik dan prostitusi yang tinggi. Keduanya merupakan faktor utama yang berperan sangat besar dalam penyebaran dan penularan HIV. Berbagai faktor resiko tersebut tidak hanya berkaitan dengan pelayanan kesehatan tetapi juga dengan masalah sosial ekonomi.

Provinsi Jambi sendiri sangat rawan terhadap kemungkinan menyebarluasnya kasus HIV/AIDS, karena letaknya dikelilingi dan berbatasan langsung dengan Provinsi tetangga yang mempunyai prevalensi HIV/AIDS relatif tinggi. Kabupaten Bungo adalah salah satu daerah otonom yang berada di provinsi Jambi. Kabupaten Bungo merupakan daerah yang menunujukkan perkembangan pesat dalam segala bidang. Perkembangan tersebut memberikan dampak negatif yang mana salah satu dampak tersebut adalah maraknya penyalahgunaan narkoba dan prostitusi terselubung. Padahal dua faktor tersebut adalah mediator penyebaran HIV/AIDS yang paling utama.

Menurut pengamatan peneliti, ada beberapa faktor yang dapat menjadi penyebab penyebaran HIV/AIDS di Kabupaten Bungo yaitu sebagai berikut:

1. Maraknya pola pergaulan yang cenderung bebas pada kalangan muda di Kabupaten Bungo;

2. Mudahnya akses terhadap situs-situs dan pengambilan akun berbau pornografi sehingga mengakibatkan meningkatnya jumlah aktivitas pornoaksi ilegal seperti adanya tempat prostitusi;

3. Minimnya pemahaman masyarakat terutama para generasi muda tentang HIV/AIDS; dan

4. Maraknya pemakaian narkoba suntik secara komunal yang rentan terhadap penyebaran HIV/AIDS.

Melihat dari faktor-faktor di atas, maka perlu dilakukan pencegahan. Kata cegah memiliki makna upaya menangkal sesuatu yang buruk sebelum terjadi. sedangkan kata pencegahan memiliki arti yang lebih spesifik dalam suatu bentuk tindakan yang riil atau nyata. Sedangkan menurut Kamus Besar Bahasa Indonesia, pencegahan adalah suatu proses, cara, perbuatan mencegah yaitu melakukan atau usaha untuk mencegah sesuatu sebelum timbul atau terjadi. Bila dilihat dari prinsip medis, upaya mencegah lebih baik daripada mengobati. Dalam penelitian ini, pencegahan berarti tindakan preventif yang dilakukan oleh Dinas Kesehatan Bungo dalam meminimalisir penyebaran HIV/AIDS.

Permasalahan tersebut perlu diatasi dengan pendekatan pelayanan kesehatan primer komprehensif yang langsung menyentuh akar permasalahan mencakup masalah sosial ekonomi dan lingkungan kultural. Maka dari itu peneliti akan mengkaitkan upaya dari Dinas Kesehatan dalam mencegah penyebaran penyakit HIV/AIDS dengan strategi dilakukan melalui berbagai langkah yang bersifat menyeluruh, meliputi tindakan sebagai berikut (Fadilah Islami, 2006:25) :

\section{Preventif}

Yaitu tindakan pencegahan sebelum terjadi penyebaran penyakit HIV/AIDS.

Dinas kesehatan sebagai garda terdepan tidak bisa hanya tinggal diam terhadap permasalahan yang terjadi, maka dari itu instansi terkait yaitu Dinas Kesehatan harus mengupayakan untuk mencegah terhadap penyebaran penyakit HIV/AIDS agar tidak meluas. Sesuai dengan Peraturan Bupati Bungo Nomor 21 Tahun 2011 tentang Uraian Tugas Pokok dan Fungsi Dinas Kesehatan Kabupaten Bungo disebutkan bahwa tugas pokok dan fungsi Kepala 
Bidang Pengendalian Masalah Kesehatan dan Kepala Seksi Pengendalian dan Pemberantasan Penyakit dengan masing-masing memiliki tugas pokok dan fungsi. Dari hasil penelitian dengan informan menjelaskan bahwa Jajarannya senantiasa berupaya untuk menjalankan pencegahan penyebaran penyakit HIV/AIDS sesuai dengan tugas dan wewenang yang dimiliki, pelaksanaan tersebut berupa pelaksanaan program seperti penyuluhan pada para pekerja seks komersial, pembagian kondom di lokasi hotspot, dan program-program lain yang berkenaan dengan pencegahan penyebaran penyakit HIV/AIDS di Kabupaten Bungo.

Dari hasil penelitian dengan informan yang lain yaitu Kepala Dinas Kesehatan Kabupaten Bungo, Upaya dalam mencegah penyebaran penyakit HIV/AIDS oleh Dinas Kesehatan Kabupaten Bungo yaitu: Mengadakan penyuluhan kepada masyarakat bahwa permasalahan HIV/AIDS adalah tanggung jawab seluruh elemen masyarakat karena HIV/AIDS bukan hanya memberikan stigma medis saja tapi juga stigma sosial dan permasalahan ini memerlukan kerjasama seluruh pihak. Dengan demikian seluruh elemen masyarakat dapat bahu-membahu dalam menghadapi permasalahan ini.

Peran utama Dinas Kesehatan dalam penanggulangan penyakit HIV/AIDS adalah sebagai pemutus rantai penyebaran penyakit HIV/AIDS. Fungsi tersebut telah berjalan dengan baik dan mengalami peningkatan. Hal ini dapat dilihat dari adanya kegiatan atau program yang telah dilaksanakan sedangkan beberapa tahun sebelumnya belum ada kegiatan atau program seperti itu.

Mengenai manfaat dan dampak dari cara pencegahan penyebaran penyakit menunjukkan ada nilai poisitif dan negatif terutama dari sektor lintas agama. Dari hasil penelitian dari lintas tokoh agama memang ada nilai positif dan negatifnya. Pertama berkaitan HIV/AIDS merupakan suatu penyakit yang berkaitan dengan ulah manusia itu sendiri yang tidak mengindahkan ajaran-ajaran luhur agama; kedua, dalam persfektif agama islam, pencegahan penyebaran penyakit HIV/AIDS melalui kondom merupakan suatu langkah yang tidak efektif karena kesannya malah memberi kesempatan untuk melakukan zina. Langkah yang paling efektif adalah dengan mentaati segala ajaran agama untuk tidak melakukan zina dan pergaulan bebas; dan ketiga, Dinas Kesehatan Kabupaten Bungo dan seluruh Badan/Instansi terkait permasalahan HIV/AIDS ini hendaknya berusaha semaksimal mungkin menjalankan peran dan kinerjanya guna membuat Kabupaten Bungo bersih dari HIV/AIDS.

Pada kesempatan lainnya yaitu Kepala Seksi Pengendalian dan Pemberantasan Penyakit mengungkapkan bahwa upaya lain yang dilakukan Dinas Kesehatan Kabupaten bungo adalah pertama meningkatkan koordinasi dan komunikasi dengan instansi lain untuk bekerjasama lebih baik dan menyamakan persepsi bahwa permasalahan HIV/AIDS adalah pemasalahan bersama. Kedua menyamakan persepsi dengan para tokoh agama atau Departemen Agama tentang langkah pemutusan rantai penyakit melalui penggunaan alat kontrasepsi berupa kondom.

Ketidaksamaan persepsi ini terkadang menimbulkan konflik yang seharusnya tidak perlu terjadi karena esensi dari permasalahan HIV/AIDS ini adalah bagaimana menanggulanginya agar tidak berkembang lebih banyak, bukan masalah bagaimana cara yang paling elegan untuk menanggulanginya.

2. Promotif.

Suatu kegiatan dan/atau serangkaian kegiatan pelayanan kesehatan yang lebih mengutamakan kegiatan yang bersifat promosi kesehatan. Yaitu tindakan berupa pemberian informasi mengenai bahaya HIV/AIDS pada masyarakat. Selain memberikan penyuluhan dalam pencegahan penyakit, upaya selanjutnya yang dilakukan oleh Dinas Kesehatan untuk mencegah penyebaran penyakit HIV/AIDS adalah memberikan informasi tentang pentingnya kesehatan, terutama tentang bahaya dan dampak dari penyakit HIV/AIDS.

Pada kesempatan lain, Kepala Seksi Pengendalian dan Pemberantasan Penyakit mengungkapkan bahwa upaya lain yang dilakukan Dinas Kesehatan Kabupaten bungo adalah dengan mengadakan penyuluhan tentang HIV/AIDS pada para generasi muda untuk mendapatkan pemahaman dan pengetahuan tentang penyakit ini. Dengan demikian secara tidak langsung akan mengurangi pergaulan bebas yang saat ini cenderung menjadi gaya hidup (life style) di kalangan generasi muda. 
3. Kuratif.

Termasuk dalam tindakan ini adalah mengenal dan mengetahui jenis penyakit pada tingkat awal serta mengadakan pengobatan yang tepat dan segera. Tujuan utama dari usaha pengobatan (kuratif) adalah pengobatan yang setepat-tepatnya dan secepat-cepatnya dari setiap jenis penyakit sehingga tercapai penyembuhan yang sempurna dan segera. Yaitu tindakan efektif berupa pengobatan medis terhadap pengidap HIV/AIDS.

Dari hasil penelitian dengan informan yaitu Kepala Dinas Kesehatan Kabupaten Bungo, Upaya dalam mencegah penyebaran penyakit HIV/AIDS yang bersifat kuratif oleh Dinas Kesehatan Kabupaten Bungo yaitu: Melakukan penyuluhan dan pembinaan kepada para Pekerja Seks Komersial (PSK) sebagai orang yang paling rentan terkena HIV/ AIDS untuk dapat melakukan tes antibodi HIV dan selalu menggunakan kondom jika memang akan berhubungan seksual agar meminimalisir kemungkinan terinfeksi. Diperlukan kesadaran untuk itu semua karena mayoritas PSK belum menyadari akan bahaya HIV/AIDS.

Pada pernyataan lain yang oleh Kepala Bidang Pengendalian Masalah Kesehatan Dinas Kesehatan Kabupaten Bungo menambahkan upaya-upaya yang dilakukan Dinas Kesehatan lainnya adalah: pertama mengusulkan untuk diperbanyak klinik penanganan HIV/AIDS dan menyebar di seluruh wilayah Kabupaten Bungo untuk meningkatkan pelayanan sekaligus memberi informasi pada masyarakat. Kedua mengusulkan agar jumlah tenaga terlatih dalam menangani penyakit HIV/AIDS ditambah dengan menumbuhkan rasa tanggung jawab pada para tenaga terlatih tersebut agar tetap fokus melaksanakan tugasnya dan tidak terpengaruh persfektif negatif yang akan timbul.

4. Rehabilitatif.

Yaitu tindakan penanganan secara psikis kepada para pengidap HIV/AIDS untuk tetap melakukan hal positif dalam hidupnya dan diikutsertakan dalam menanggulangi HIV/AIDS. Proses rehabilitatif adalah usaha untuk mengembalikan bekas penderita ke dalam masyarakat, sehingga dapat berfungsi lagi sebagai anggota masyarakat yang berguna untuk dirinya dan masyarakat sesuai dengan kemampuannya. Usaha rehabilitasi ini memerlukan bantuan dan pengertian dari seluruh anggota masyarakat untuk dapat mengerti dan memahami keadaan mereka (bekas penderita), sehingga memudahkan mereka (bekas penderita) dalam proses penyesuaian dirinya dalam masyarakat dengan kondisinya yang sekarang ini.

Rehabilitasi terdiri dari :

a. Rehabilitasi fisik, yaitu agar penderita memperoleh perbaikan fisik semaksimalnya.

b. Rehabilitasi mental, yaitu agar bekas penderita dapat menyesuaikan diri dalam hubungan perorangan dan sosial secara memuaskan.

c. Rehabilitasi sosial vokasional, yaitu agar bekas pendirita menempati suatu pekerjaan atau jabatan dalam masyarakat dengan kapasitas kerja yang semaksimal mungkin sesuai dengan kemampuannya.

d. Rehabilitasi aesthetis, yaitu usaha yang dilakukan untuk mengembalikan rasa keindahan dari bagian anggota tubuh, walaupun fungsinya tidak bekerja seperti anggota tubuh aslinya.

Secara keseluruhan upaya-upaya yang dilakukan oleh dinas kesehatan Kabupaten Bungo sudah maksimal, tetapi dalam pelaksanaannya ada faktor-faktor yang menjadi penghambat, di antaranya adalah: Pertama kerap kali terjadi miskomunikasi antara Dinas Kesehatan dan Komisi Penenggulangan AIDS dengan instansi penegak hukum yang memiliki wewenang untuk mengadakan razia di titik-titik hotspot terhadap para pekerja seks komersial. Hal ini mengakibatkan kesulitan untuk menyentuh para PSK tersebut karena mereka ketakutan terlebih dahulu dan menganggap tim dari Dinas Kesehatan dan KPA akan menangkap mereka. Padahal tujuan Dinas Kesehatan dan KPA hanya ingin memberi penyuluhan, membagi-bagikan alat kontrasepsi (kondom) atau melakukan tes antibodi HIV pada mereka, bukan menangkap dan menghukum mereka. Kedua masih rendahnya pengetahuan dan kesadaran para PSK yang merupakan orang paling rentan terkena HIV/AIDS akan HIV/AIDS itu sendiri untuk memeriksakan dirinya pada instansi terkait telah terinfeksi atau tidak. Hal ini jelas akan memberi efek bahaya dikarenakan para PSK dapat menyebarkan HIV/AIDS kepada orang lain. Ketiga Kerap terjadi kesalahpahaman antara Dinas Kesehatan dan KPA dengan 
Departemen Agama atau Ormas Islam mengenai penanganan HIV/AIDS di Kabupaten Bungo terutama dalam masalah pembagian alat kontrasepsi berupa kondom.

Menurut mayoritas kalangan religi, penggunaan kondom bukan suatu solusi malah seakan melegalkan prostitusi terjadi di Kabupaten Bungo. Di sisi lain, satu-satunya alat yang dapat memutus rantai penyebaran HIV/AIDS sejauh ini adalah kondom dan telah terbukti baik melalui tes uji secara elektronik maupun fakta-fakta yang ada di lapangan.

\section{KESIMPULAN DAN SARAN}

Berdasarkan hasil penelitian dan pembahasan di atas, peneliti menarik kesimpulan bahwa upaya yang dilakukan melalui berbagai langkah yang bersifat menyeluruh, meliputi preventif, promotif, kuratif, dan rehabilitatif dengan partisipasi dan kerja sama yang luas yang melibatkan berbagai sektor dan organisasi non pemerintah dan masyarakat telah cukup baik dan mengalami kemajuan namun masih harus ditingkatkan lagi agar Kabupaten Bungo dapat bersih dari HIV/AIDS. Upaya-Upaya tersebut adalah seperti dengan mengadakan penyuluhan kepada masyarakat bahwa permasalahan HIV/AIDS adalah tanggung jawab seluruh elemen masyarakat, melakukan penyuluhan dan pembinaan kepada para Pekerja Seks Komersial (PSK) sebagai orang yang paling rentan terkena HIV/ AIDS, dan meningkatkan koordinasi dan komunikasi dengan instansi lain untuk bekerjasama lebih baik dan menyamakan persepsi bahwa permasalahan HIV/AIDS adalah pemasalahan bersama.

Adapun saran yang dapat peneliti ajukan untuk meningkatkan kinerja Dinas Kesehatan Kabupaten Bungo dalam upaya mencegah penyebaran penyakit HIV/AIDS di Kabupaten Bungo yaitu pertama hendaknya Dinas Kesehatan lebih terbuka untuk melakukan kerjasama dengan pihak-pihak lain yang menaruh rasa perhatian dan simpatik terhadap permasalahan HIV/AIDS di Kabupaten Bungo. Kedua Dinas Kesehatan selaku instansi yang memiliki tanggung jawab lebih besar dalam hal penanganan kesehatan hendaknya selalu mengadakan koordinasi dan sharing dengan Dinas/Badan/Instansi lain baik milik pemerintah maupun independent tentang program-program, rencana aksi dan sejenisnya sehingga tidak menimbulkan miskomunikasi ketika memasuki tahap praktek di lapangan. Ketiga Dinas Kesehatan mesti mampu mencitrakan bahwa Orang Dengan HIV/AIDS (ODHA) bukanlah penjahat sosial atau orang yang harus dihindari. Adanya rasa apatis dan diskriminatif hanya akan membuat fenomena gunung es lebih lama terjadi.

\section{REFERENSI}

Budi, Setyo W. 2009. Waspada Bahaya AIDS, Musi Perkasa Utama. Jakarta.

Fadilah, Islam. 2006. Fenomena AIDS. Rosdakarya. Bandung.

Jhonatan Weber dan Annael Ferriman. 1993. Aids dan Anda, Arcan. Jakarta.

Kresno, S. B. 2010. Imunologi: Dignosis dan Prosedur Laboratorium. Edisi Kelima. Badan Penerbit Fakultas Kedokteran UI. Jakarta.

Mulyadi, Muhammad. 2012. Penelitian Kuantitatif dan Kualitatif serta Praktek Kombinasinya dalam Penelitian Sosial. Jakarta: Publica Institute.

Notoatmodjo, S . 2010. Ilmu Prilaku Kesehatan. Cetakan Pertama. Rineka Cipta. Jakarta.

Pasolong, Harbani. 2013. Teori Administasi Publik. Alfabeta. Bandung.

Sugiyono, 2010. Metode Penelitian Administrasi. Alfabeta. Jakarta.

Usman, Husaini dan Purnomo Setiadi. A, 2003. Metodologi Penelitian Sosial, Bumi Aksara, Jakarta 